\title{
Metode optimasi pada interkoneksi sistem suplai uap untuk kehandalan dan ekonomi pada sea water desalination
}

\author{
Angga Ridwan Pratama ${ }^{1}$, Muhammad Agus Sahbana ${ }^{2}$, Nova Risdiyanto Ismail ${ }^{3}$ \\ Jurusan Teknik Mesin, Fakultas Teknik, Universitas Widyagama Malang ${ }^{1,2,3}$ \\ Jl. Taman Borobudur Indah No. 3, Lowokwaru Malang 65141, Indonesia \\ Email: angga.ridwan.p@gmail.com¹,sahbana@widyagama.ac.id², novajota@yahoo.com³
}

\begin{abstract}
Sea water desalination or desalination plant is an equipment that functions to change sea water into fresh water. Its reliability in supply water is important especially as raw material for the electricity generation process. Start-stop gas turbine operating mode as well as routine maintenance schedules or sudden damage in one of the desalination plant s cause a reduction in steam supply readiness. This research purposed to maintain the availability of supply steam desalination plant by using a method design interconnection line which is analyzed in terms of pressure drop and flow in theoretical calculations. This research resulted is design the interconnection line supply steam of the desalination plant by removing and modifying the position of the check valve dividing between desalination plant 1, 2 and 3. The analysis of the supply steam interconnection design in terms of pressure and flow desalination plant is still in accordance with the reference manual book. The operational cost of the desalination plant is more economical using supply steam from Block 1 Low-Pressure Auxiliary with a profit of $154.01 \%$ or $82,318,148$ rupiahs per day.
\end{abstract}

Keywords: Sea water desalination, interconnection line, pressure drop, flow, operational cost.

\begin{abstract}
Abstrak
Sea water desalination atau desalination plant adalah suatu peralatan yang berfungsi untuk menyuling air laut menjadi air tawar. Kehandalannya dalam menyediakan air menjadi hal yang penting terutama sebagai bahan baku proses pembangkitan listrik. Mode pengoperasian gas turbin yang start-stop serta adanya schedule pemeliharaan rutin atau gangguan pada salah satu desalination plant menyebabkan berkurangnya kesiapan suplai uap. Penelitian ini bertujuan untuk menjaga ketersediaan suplai uap desalination plant dengan menggunakan metode perancangan line interkoneksi yang dianalisa dari segi pressure drop dan perubahan flow secara perhitungan teoritis. Penelitian ini menghasilkan rancangan interkoneksi line suplai uap desalination plant dengan cara melepas dan memodifikasi posisi check valve pemisah antara desalination plant 1,2 dan 3. Analisa rancangan interkoneksi suplai uap dari segi pressure dan flow desalination plant masih sesuai dengan referensi manual book. Biaya operasional desalination plant lebih ekonomis menggunakan suplai uap dari Low Pressure Auxiliarry Blok 1 dengan keuntungan sebesar 154,01\% atau 82.318.148 rupiah per hari.

Kata Kunci: Sea water desalination, line interkoneksi, pressure drop, flow, biaya operasional.
\end{abstract}

\section{Pendahuluan}

Sea water desalination atau desalination plant merupakan suatu peralatan yang berfungsi untuk menyuling air laut yang mempunyai conductivity di atas $50.000 \mu \mathrm{mhos} / \mathrm{cm}$ menjadi air tawar dengan conductivity di bawah 10 $\mu \mathrm{mhos} / \mathrm{cm}$. Secara proses desalination plant menggunakan bahan baku air laut yang dipanasi oleh uap. Air laut tersebut berubah menjadi uap di dalam brine heater. Kemudian uap tersebut didinginkan sehingga diperoleh distillate water atau air tawar [1]. 
Pembangkit Listrik Tenaga Gas Uap (PLTGU) Grati Pasuruan mempunyai 3 unit desalination plant (desal) yang pengoperasiannya dibantu dengan uap dari Auxiliary boiler, low pressure (LP) Auxiliary Steam Blok 1 dan Cold Reheat (CRH) steam blok 3. Desal 1 dan desal 2 disuplai dari Auxiliary boiler dan LP Steam Blok 1 [2]. Sedangkan desal 3 hanya disuplai dari Auxiliary boiler dan CRH blok 3 [3]. Auxiliary boiler dijadikan alternatif terakhir dikarenakan bahan bakar yang digunakan yaitu high speed diesel (HSD) yang notabene tidak ramah lingkungan. Sehingga pengoperasian desalination plant diutamakan disuplai oleh uap dari LP steam blok 1 untuk desal 1 dan 2 sedangkan CRH untuk suplai uap desal 3. Mode pengoperasian gas turbin yang start-stop serta adanya schedule pemeliharaan rutin atau gangguan pada salah satu desalination plant menyebabkan berkurangnya kesiapan suplai uap. Sehingga diperlukan suatu penelitian untuk menjaga ketersediaan suplai uap desalination plant.

Penelitian yang membahas mengenai sumber daya yang sesuai untuk desalination plant. Mengintegrasikan multi-effect desalination (MED) unit dengan internal combustion engine (ICE). Panas gas buang ICE digunakan untuk menghasilkan uap sesuai kebutuhan panas untuk efek pertama sistem MED [4]. Selain itu, juga menganalisa integrasi unit multieffect desalination (MED) dengan sistem jaringan uap. Analisis termodinamika dan ekonomi menunjukkan bahwa memanfaatkan uap MP memiliki tingkat produksi air desalinasi tertinggi dan menggunakan uap LP memiliki efisiensi terbaik [5].

Penelitian untuk menganalisa mengenai sea water desalination yang cocok untuk masa depan. Analisa dilakukan dengan membandingkan sea water desalination dari segi energi, teknologi, dan peralatan [6].

Penelitian yang berisi tentang analisa flow rate dan pressure drop pada compressible superheated steam yang dilakukan dengan metode eksperimen kemudian dibandingkan dengan perhitungan numerik [7].

Dari penelitian tersebut, maka penulis dapat mengambil referensi untuk memecahkan permasalahan pada sea water desalination terutama di PLTGU Grati dengan cara melakukan interkoneksi suplai uap sehingga menghasilkan desalination plant yang handal.

\section{Tinjauan Teoritis}

Tinjauan teoritis dari penelitian ini menggunakan teori penurunan tekanan perpipaan. Penuruan tekanan pada sistem perpipaan disebabkan oleh faktor-faktor berikut [8]:

\section{Rugi-rugi Mayor}

Rugi mayor adalah rugi yang terjadi akibat adanya gesekan aliran fluida dengan dinding pipa pada pipa lurus. Profil aliran fluida dalam pipa ditentukan dari bilangan Reynolds, yaitu:

$$
\operatorname{Re}=\frac{\rho x V x D}{\mu}
$$

Keterangan:

$$
\begin{aligned}
& \mathrm{V}=\text { Kecepatan fluida }(\mathrm{m} / \mathrm{s}) \\
& \rho=\operatorname{Massa} \text { jenis fluida }\left(\mathrm{kg} / \mathrm{m}^{3}\right) \\
& \mathrm{D}=\operatorname{Diameter} \text { pipa }(\mathrm{m}) \\
& \mu=\operatorname{Viscositas} \text { dinamik fluida }\left(\mathrm{N} . \mathrm{s} / \mathrm{m}^{2}\right) \\
& \quad \text { Kecepatan fluida }(\mathrm{V}) \text { pada Reynold }
\end{aligned}
$$
dapat dicari dengan menggunakan persamaan sebagai berikut:

$$
\mathrm{Q}=\mathrm{VxA} \quad \text { jadi }, \quad \mathrm{V}=\frac{\mathrm{Q}}{\mathrm{A}}
$$

Keterangan

$$
\begin{aligned}
& \mathrm{V}=\operatorname{Kecepatan}(\mathrm{m} / \mathrm{s}) \\
& \mathrm{Q}=\text { Flowrate }\left(\mathrm{m}^{3} / \mathrm{s}\right) \\
& \mathrm{A}=\text { Luas penampang }(\mathrm{m}) \\
& \text { Jenis aliran berdasarkan bilangan }
\end{aligned}
$$
Reynold ada tiga macam, yaitu:

1. Aliran laminar, $\operatorname{Re}<2300$

2. Aliran transisi, $2300<\operatorname{Re}<4000$

3. Aliran turbulen, $\operatorname{Re}>4000$

Aliran laminar memiliki profil aliran yang seragam dan memiliki kecepatan relatif rendah. Aliran turbulen memiliki profil aliran yang acak dan kecepatan aliran yang tinggi. Sedangkan aliran transisi 
memiliki pola dimana profil aliran berubah dari seragam menjadi acak.

Untuk aliran turbulen, nilai faktor gesekan tergantung pada bilangan Reynolds, kekasaran relatif pipa, dan diameter pipa. Ada dua cara menghitung nilai faktor gesekan untuk aliran turbulen, yaitu menggunakan diagram Moody dan persamaan Colebrook. Untuk memperoleh hasil yang lebih akurat, persamaan Colebrook lebih cocok digunakan. Akan tetapi, persamaan ini merupakan persamaan implisit sehingga perlu dilakukan beberapa kali iterasi untuk memperoleh nilai faktor gesekan. Sedangkan diagram Moody lebih mudah digunakan dan cepat, tetapi nilai faktor gesekan yang diperoleh tidak seakurat menggunakan persamaan Colebrook. Persamaan Colebrook dapat ditulis seperti persamaan berikut.

$$
\frac{1}{\sqrt{\mathrm{f}}}=-2,0 \log \left(\frac{\epsilon / \mathrm{D}}{3,7}+\frac{2,51}{\operatorname{Re} \sqrt{\mathrm{f}}}\right)
$$

Keterangan:

$$
\begin{aligned}
& \mathrm{f}=\text { Faktor gesekan } \\
& \varepsilon=\text { Kekasaran relatif pipa }(\mathrm{m}) \\
& \mathrm{D}=\text { Diameter-dalam pipa }(\mathrm{m}) \\
& \operatorname{Re}=\text { Bilangan Reynolds }
\end{aligned}
$$

Selain itu, rugi-rugi mayor ditentukan oleh faktor gesekan yang terjadi pada dinding pipa yang ditunjukan dengan nilai $\mathrm{f}$ atau Friction factor. Nilai f dapat dicari melalui diagram moody dan harus diketahui terlebih dahulu nilai relative roughnes yang dapat dicari dengan menggunakan persamaan sebagai berikut:

$$
\text { Relative Roughness }=\mathrm{e} / \mathrm{D}
$$

Keterangan:

$$
\begin{aligned}
& E=\text { Roughness pipa } \\
& \mathrm{D}=\text { Diameter pipa } \\
& \text { Roughness pipa atau kekasaran pipa } \\
& \text { dapat dilihat pada Tabel } 1 .
\end{aligned}
$$

Tabel 1. Kekasaran pipa

\begin{tabular}{lcc}
\hline \multirow{2}{*}{ Pipe } & \multicolumn{2}{c}{ Equivalent Roughness, $\varepsilon$} \\
\cline { 2 - 3 } & Feet & Milimeters \\
\hline Riveted steel & $0.003-0.03$ & $0.9-9.0$ \\
\hline Concrete & $0.001-0.01$ & $0.3-3.0$ \\
\hline Wood Stave & $\begin{array}{c}0.0006- \\
0.003\end{array}$ & $0.18-0.9$ \\
\hline Cast iron & 0.00085 & 0.26 \\
\hline Galvanized iron & 0.0005 & 0.15 \\
\hline $\begin{array}{l}\text { Commercial steel } \\
\text { or wrought iron }\end{array}$ & 0.00015 & 0.045 \\
\hline Drawn tubing & 0.000005 & 0.0015 \\
\hline Plastic, glass & $0.0($ smooth $)$ & $0.0($ smooth $)$ \\
\hline
\end{tabular}

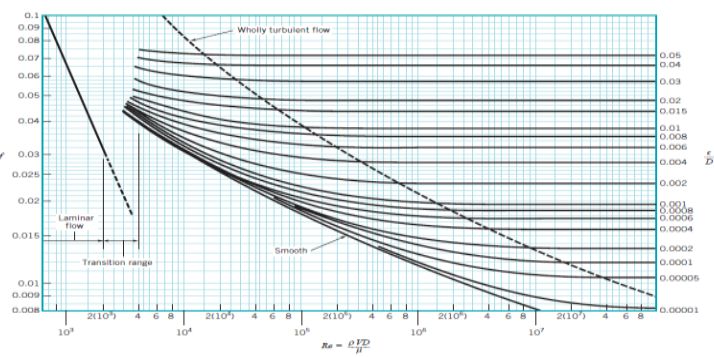

Gambar 1. Diagram Moody

Dari persamaan-persamaan di atas, perhitungan rugi-rugi mayor menurut Darcy-Weisbach, dapat dihitung dengan menggunakan persamaan sebagai berikut:

$$
h l=f \cdot \frac{L}{d} \cdot \frac{V^{2}}{2 g}
$$

Keterangan:

$$
\begin{aligned}
& \mathrm{h}_{1}=\text { Kehilangan tekanan mayor }(\mathrm{Pa}) \\
& \mathrm{f}=\text { Friction factor } \\
& \mathrm{L}=\text { Panjang pipa }(\mathrm{m}) \\
& \mathrm{d}=\text { Diameter pipa }(\mathrm{m}) \\
& \mathrm{V}=\operatorname{Kecepatan} \text { fluida }(\mathrm{m} / \mathrm{s}) \\
& \mathrm{g}=\text { Percepatan gravitasi }\left(\mathrm{m} / \mathrm{s}^{2}\right)
\end{aligned}
$$

\section{Rugi-rugi Minor}

Rugi-rugi minor adalah kerugian tekanan yang disebabkan karena adanya sambungan pipa seperti katup, belokan, saringan, percabangan, losess pada bagian masuk, losses pada bagian keluar, pembesaran pipa, pengecilan pipa dan sebagainya. Rugi-rugi minor dapat dihitung dengan menggunakan rumus sebagai berikut:

$$
h l m=k \cdot \frac{V^{2}}{2 g}
$$

Keterangan:

$$
\begin{aligned}
& \mathrm{h}_{1 \mathrm{~m}}=\text { Kehilangan tekanan minor }(\mathrm{Pa}) \\
& \mathrm{k}=\text { Koefisien hambatan } \\
& \mathrm{V}=\operatorname{Kecepatan} \text { fluida }(\mathrm{m} / \mathrm{s}) \\
& \mathrm{g}=\text { Percepatan gravitasi }\left(\mathrm{m} / \mathrm{s}^{2}\right)
\end{aligned}
$$




\section{Penurunan tekanan total pemipaan}

Penurunan tekanan total pemipaan yang disebabkan oleh jalur distribusi pemipaan dapat dicari dengan menjumlahkan rugi-rugi mayor dengan rugi-rugi minor. Adapun persamaannya adalah sebagai berikut:

Total Losses $=$ hl mayor + hlm minor

\section{Metode Penelitian}

Penelitian ini menggunakan metode antara lain: studi literatur, studi lapangan, perancangan line interkoneksi sistem suplai uap, analisa kelayakan dan analisa ekonomi.

\section{Tempat dan waktu pelaksanaan}

Penelitian ini dilakukan di PT. Indonesia Power UPJP Perak dan Grati yang beralamat di Jl Raya Surabaya Probolinggo $\mathrm{Km} 73$ Desa Wates Kecamatan Lekok Kabupaten Pasuruan Jawa Timur. Penelitian ini dilakukan mulai bulan Januari 2019 sampai dengan Agustus 2019.

\section{Variabel penelitian}

Variabel yang digunakan pada penelitian ini meliputi variabel terikat dan variabel bebas. Variabel terikat terdiri dari flow dan pressure suplai uap yang menuju desalination plant. Sedangkan variabel bebas pada penelitian ini adalah desain valve dan pipa.

\section{Diagram alir penelitian}

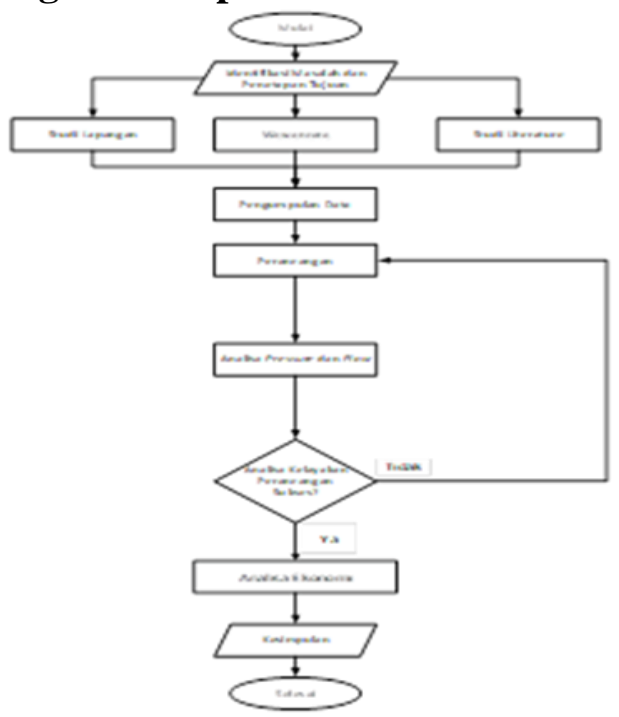

Gambar 2. Diagram alir penelitian

\section{Hasil dan pembahasan}

1. Hasil perancangan interkoneksi

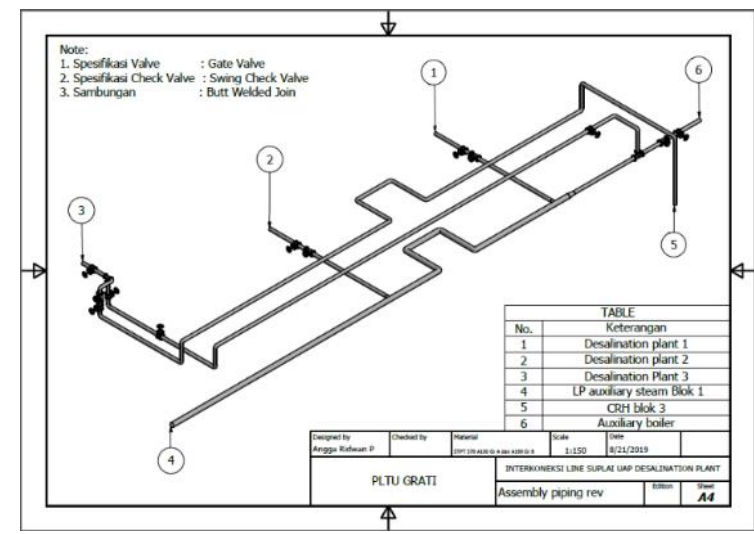

Gambar 3. Perancangan interkoneksi

Desain dibuat dengan skala 1:50 menggunakan software desaign inventor 2020. Material pipa menggunakan STPT 370 A160 Gr A \& B. Spesifikasi valve menggunakan tipe Gate Valve dan check valve menggunakan tipe swing check valve. Setiap sambungan pada pipa menggunakan tipe Butt Welded Joint.

\section{Parameter desalination plant berdasarkan manual book}

Tabel 2. Parameter desalination plant [9, 10]

\begin{tabular}{ccccccc}
\multicolumn{1}{c}{$\begin{array}{c}\text { Parameter } \\
\begin{array}{l}\text { Load } \\
\text { Setter }\end{array}\end{array}$} & $\begin{array}{c}\text { Desalination } \\
\text { Plant 1 }\end{array}$ & \multicolumn{2}{c}{$\begin{array}{c}\text { Desalination } \\
\text { Plant 2 }\end{array}$} & \multicolumn{2}{c}{$\begin{array}{c}\text { Desalination } \\
\text { Plant 3 }\end{array}$} \\
\hline $\begin{array}{c}\text { Pressure } \\
(\mathbf{b a r})\end{array}$ & $\begin{array}{c}\text { Flow } \\
(\mathbf{k g} / \mathbf{h})\end{array}$ & $\begin{array}{c}\text { Pressure } \\
(\mathbf{b a r})\end{array}$ & $\begin{array}{c}\text { Flow } \\
(\mathbf{k g} / \mathbf{h})\end{array}$ & $\begin{array}{c}\text { Pressure } \\
(\mathbf{b a r})\end{array}$ & $\begin{array}{c}\text { Flow } \\
(\mathbf{k g} / \mathbf{h})\end{array}$ \\
\hline $60 \%$ & $3-7$ & $\begin{array}{c}3400- \\
3700\end{array}$ & $3-7$ & $3400-$ & $5-7$ & 3863 \\
\hline $80 \%$ & $3-7$ & $\begin{array}{r}4500- \\
5000\end{array}$ & $3-7$ & $\begin{array}{c}4500- \\
5000\end{array}$ & $5-7$ & 5286 \\
\hline $100 \%$ & $3-7$ & $\begin{array}{c}6190- \\
6800\end{array}$ & $3-7$ & $\begin{array}{c}6190- \\
6800\end{array}$ & $5-7$ & 6800 \\
\hline
\end{tabular}

3. Data parameter desalination plant sebelum interkoneksi

Tabel 3. Parameter desalination plant 1

\begin{tabular}{ccccc}
\hline \multicolumn{5}{c}{ Suplai Uap dari LP Auxiliary Steam } \\
Blok 1 \\
\cline { 2 - 5 } No & $\begin{array}{c}\text { Load } \\
\text { Setter } \\
(\%)\end{array}$ & $\begin{array}{c}\text { Flow } \\
(\mathrm{kg} / \mathrm{h})\end{array}$ & $\begin{array}{c}\text { Pressure } \\
(\text { Bar })\end{array}$ & $\begin{array}{c}\text { Wakt } \\
\mathrm{u} \\
(\mathrm{Jam})\end{array}$ \\
\hline 1. & 60 & 3665 & 5,12 & 1 \\
\hline 2. & 60 & 3623 & 4,96 & 1 \\
\hline 3. & 60 & 3634 & 4,95 & 1 \\
\hline 4. & 60 & 3641 & 5,15 & 1 \\
\hline 5. & 60 & 3669 & 5,08 & 1 \\
\hline Rata-rata & 3646,88 & 5,09 & \\
\hline \multicolumn{5}{r}{} \\
\end{tabular}


Tabel 4. Parameter desalination plant 2

\begin{tabular}{|c|c|c|c|c|}
\hline \multirow[b]{2}{*}{ No } & \multicolumn{4}{|c|}{$\begin{array}{l}\text { Suplai Uap dari LP Auxiliary Steam } \\
\text { Blok } 1\end{array}$} \\
\hline & $\begin{array}{c}\text { Load } \\
\text { Setter } \\
(\%)\end{array}$ & $\begin{array}{l}\text { Flow } \\
(\mathrm{kg} / \mathrm{h})\end{array}$ & $\begin{array}{r}\text { Pressur } \\
e \text { (Bar) }\end{array}$ & $\begin{array}{c}\text { Wakt } \\
\text { u } \\
\text { (Jam) }\end{array}$ \\
\hline 1. & 60 & 3665 & 5,12 & 1 \\
\hline 2. & 60 & 3623 & 4,96 & 1 \\
\hline 3. & 60 & 3634 & 4,95 & 1 \\
\hline 4. & 60 & 3641 & 5,15 & 1 \\
\hline 5. & 60 & 3669 & 5,08 & 1 \\
\hline & ta-rata & 3646,88 & 5,09 & \\
\hline
\end{tabular}

Tabel 5. Parameter desalination plant 3

\begin{tabular}{|c|c|c|c|c|}
\hline \multirow{3}{*}{ No } & \multicolumn{4}{|c|}{ Suplai Uap dari CRH Blok 3} \\
\hline & Load & & Pressu & Wakt \\
\hline & $\begin{array}{c}\text { Setter } \\
(\%)\end{array}$ & 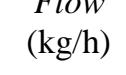 & $\begin{array}{c}r e \\
\text { (Bar) }\end{array}$ & $\begin{array}{c}\mathrm{u} \\
(\mathrm{Jam})\end{array}$ \\
\hline 1. & 60 & 3745,22 & 5,29 & 1 \\
\hline 2. & 60 & 3751,07 & 5,30 & 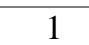 \\
\hline 3. & 60 & 3758,87 & 5,31 & 1 \\
\hline 4. & 60 & 3749,12 & 5,30 & 1 \\
\hline 5. & 60 & 3749,12 & 5,29 & 1 \\
\hline & -rata & 3749,37 & 5,29 & \\
\hline
\end{tabular}

4. Data parameter desalination plant setelah interkoneksi

Perhitungan pressure drop dan penurunan flow secara teoritis menggunakan persamaan teoritis dapat dirangkum pada tabel 6 , sebagai berikut:

Tabel 6. Parameter desalination plant 1 [1]

No Suplai Uap dari LP Auxiliary Steam Blok 1

\begin{tabular}{ccccc}
\cline { 2 - 5 } & $\begin{array}{c}\text { Load } \\
\text { Setter } \\
(\%)\end{array}$ & $\begin{array}{c}\text { Flow } \\
(\mathrm{kg} / \mathrm{h})\end{array}$ & $\begin{array}{c}\text { Pressure } \\
(\text { Bar })\end{array}$ & $\begin{array}{c}\text { Waktu } \\
(\mathrm{Jam})\end{array}$ \\
\hline 1. & 60 & 4115,86998 & 5,28548 & 1 \\
\hline 2. & 60 & 4122,47434 & 5,28576 & 1 \\
\hline 3. & 60 & 4131,04497 & 5,28568 & 1 \\
\hline 4. & 60 & 4120,33168 & 5,28564 & 1 \\
\hline 5. & 60 & 4120,15512 & 5,28545 & 1 \\
\hline \multicolumn{2}{l}{ Rata-rata } & 4121,97522 & 5,28560 & \\
\hline
\end{tabular}

Tabel 7 Parameter desalination plant 2

No Suplai Uap dari LP Auxiliary Steam

Blok 1

\begin{tabular}{cccc}
\hline Load & Flow & Pressure & Waktu \\
Setter & $(\mathrm{kg} / \mathrm{h})$ & (Bar) & (Jam)
\end{tabular}

\begin{tabular}{crrrr}
\multicolumn{5}{c}{$(\%)$} \\
\hline 1. & 60 & 4115,60545 & 5,28514 & 1 \\
\hline 2. & 60 & 4122,29768 & 5,28542 & 1 \\
\hline 3. & 60 & 4130,77944 & 5,28535 & 1 \\
\hline 4. & 60 & 4120,06684 & 5,28530 & 1 \\
\hline 5. & 60 & 4119,89030 & 5,28511 & 1 \\
\hline Rata-rata & 4121,72794 & 5,28526 & \\
\hline
\end{tabular}

Tabel 8. Parameter desalination plant 3

\begin{tabular}{ccccc}
\hline No & \multicolumn{4}{c}{ Suplai Uap dari CRH Blok 3 } \\
\cline { 2 - 5 } & $\begin{array}{c}\text { Load } \\
\text { Setter } \\
(\%)\end{array}$ & $\begin{array}{c}\text { Flow } \\
(\mathrm{kg} / \mathrm{h})\end{array}$ & $\begin{array}{c}\text { Pressure } \\
\text { (Bar) }\end{array}$ & $\begin{array}{c}\text { Waktu } \\
\text { (Jam) }\end{array}$ \\
\hline $\mathbf{1 .}$ & 60 & 3651,29817 & 5,11341 & 1 \\
\hline $\mathbf{2 .}$ & 60 & 3609,45519 & 5,11332 & 1 \\
\hline $\mathbf{3 .}$ & 60 & 3620,31941 & 5,11321 & 1 \\
\hline $\mathbf{4 .}$ & 60 & 3627,38789 & 5,11335 & 1 \\
\hline $\mathbf{5 .}$ & 60 & 3655,28321 & 5,11335 & 1 \\
\hline Rata-rata & 3632,74877 & 5,11333 & \\
\hline
\end{tabular}

\section{Nilai deviasi parameter desalination plant}

Tabel 9. Pressure dan flow desalination plant

\begin{tabular}{|c|c|c|c|c|}
\hline \multirow{2}{*}{ Parameter } & \multicolumn{2}{|c|}{$\begin{array}{l}\text { Data Sebelum } \\
\text { Perancangan }\end{array}$} & \multirow{2}{*}{$\begin{array}{c}\begin{array}{c}\text { Data Setelah } \\
\text { Perancangan }\end{array} \\
\text { Perhitungan } \\
\text { Manual }\end{array}$} & \multirow{2}{*}{$\begin{array}{c}\text { Nilai } \\
\text { Deviasi }\end{array}$} \\
\hline & $\begin{array}{c}\text { Data } \\
\text { Operasi }\end{array}$ & $\begin{array}{c}\text { Manual } \\
\text { book }\end{array}$ & & \\
\hline $\begin{array}{l}\begin{array}{l}\text { Pressure } \\
\text { desal } 1 \text { (Bar) }\end{array} \\
\end{array}$ & 5,09 & $3-7$ & 5,28 & $+0,17$ \\
\hline $\begin{array}{l}\text { Flow } \\
\text { desal } 1(\mathrm{Kg} / \mathrm{h})\end{array}$ & 3646,88 & $\begin{array}{c}3400- \\
6800 \\
\end{array}$ & 4121,97 & $+475,09$ \\
\hline $\begin{array}{l}\text { Pressure } \\
\text { desal } 2 \text { (bar) }\end{array}$ & 5,09 & $3-7$ & 5,28 & $+0,17$ \\
\hline $\begin{array}{l}\text { Flow } \\
\text { desal } 2 \text { (Bar) }\end{array}$ & 3646,88 & $\begin{array}{c}3400- \\
6800\end{array}$ & 4121,97 & $+475,09$ \\
\hline $\begin{array}{l}\text { Pressure } \\
\text { desal } 3 \text { (bar) }\end{array}$ & 5,29 & $5-7$ & 5,11 & $-0,18$ \\
\hline $\begin{array}{l}\text { Flow } \\
\text { desal } 3(\mathrm{~kg} / \mathrm{h})\end{array}$ & 3749,37 & $\begin{array}{l}3863- \\
6800\end{array}$ & 3632,74 & - 116,63 \\
\hline
\end{tabular}

\section{Perhitungan ekonomi biaya operasional desalination plant}

Ketika sudah terjadi interkoneksi line suplai uap desalination plant, maka pengoperasian desalination plant dapat lebih fleksibel dalam memilih suplai uap yang dgunakan untuk mengoperasikan desal. Dengan adanya interkoneksi maka desalination plant 1, 2 dan 3 dapat dapat menggunakan suplai steam dari LP Aux Blok 1, CRH Blok 3 maupun Aux Boiler. Sehingga dapat menambah keuntungan ekonomi dengan mengoperasikan desalination plant menggunakan suplai steam yang paling murah. Untuk menghitung biaya operasional desalination plant dalam kurun waktu 24 jam menggunakan parameter pemakaian steam dan pemakaian listrik untuk mengoperasikan peralatan-peralatan pada desalination plant. 
Tabel 10. Biaya operasional desal

\begin{tabular}{|c|c|c|c|}
\hline $\begin{array}{r}\begin{array}{r}\text { Suplai } \\
\text { steam }\end{array} \\
\text { Parameter }\end{array}$ & $\begin{array}{c}\text { Steam dari } \\
\text { LP Aux } \\
\text { Blok } 1\end{array}$ & $\begin{array}{c}\text { Steam dari } \\
\text { CRH Blok } \\
3\end{array}$ & $\begin{array}{l}\text { Steam dari } \\
\text { Aux boiler }\end{array}$ \\
\hline $\begin{array}{l}\text { Desalination } \\
\text { plant } 1\end{array}$ & $\begin{array}{c}\mathrm{Rp} \\
53.451 .420\end{array}$ & $\begin{array}{c}\mathrm{Rp} \\
69.339 .420\end{array}$ & $\begin{array}{c}\mathrm{Rp} \\
135.769 .568\end{array}$ \\
\hline $\begin{array}{l}\text { Desalination } \\
\text { plant } 2\end{array}$ & $\begin{array}{c}\mathrm{Rp} \\
53.451 .420\end{array}$ & $\begin{array}{c}\mathrm{Rp} \\
69.339 .420\end{array}$ & $\begin{array}{c}\mathrm{Rp} \\
135.769 .568\end{array}$ \\
\hline $\begin{array}{l}\text { Desalination } \\
\text { plant } 3\end{array}$ & $\begin{array}{c}\mathrm{Rp} \\
53.469 .834\end{array}$ & $\underset{69.357 .834}{R p}$ & $\begin{array}{c}\mathrm{Rp} \\
135.787 .982\end{array}$ \\
\hline
\end{tabular}

\section{Pembahasan pressure dan flow} desalination plant 1

Dari data manual book, operasi desalination plant 1 dan perhitungan teoritis, maka dapat dibuat perbandingan pressure desalination plant 1 seperti pada gambar 4 dan perbandingan flow desalination plant 1 seperti pada gambar 5 , sebagai berikut:

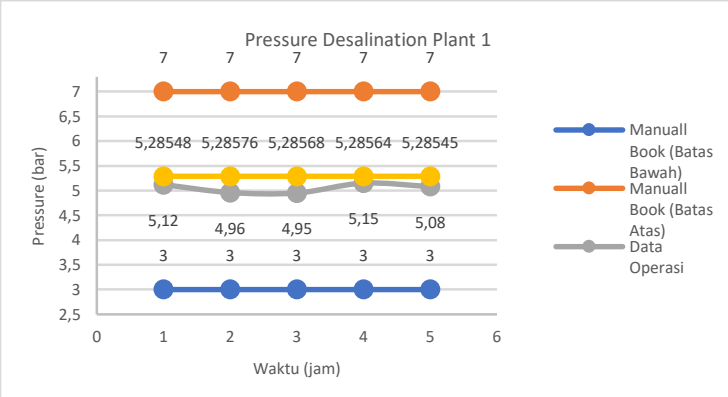

Gambar 4. Perbandingan pressure desalination plant 1

Dari gambar 4, data operasi merupakan data pressure desalination plant 1 ketika beroperasi sebelum adanya interkoneksi yakni ketika menggunakan suplai steam dari LP Aux blok 1 . Perhitungan merupakan pressure input desalination plant 1 setelah adanya interkoneksi, yakni ketika menggunakan suplai steam dari CRH blok 3. Dari gambar 4, dapat dianalisa bahwa pressure desalination plant 1 sebelum interkoneksi, yakni ketika menggunakan suplai steam dari LP Aux blok 1 (data operasi) dan sesudah penelitian, yakni ketika menggunakan suplai steam dari CRH Blok 3 (perhitungan) masih sesuai dengan referensi manual book, sehingga interkoneksi dari CRH Blok 3 ke Desalination plant 1 dapat dinyatakan layak digunakan.

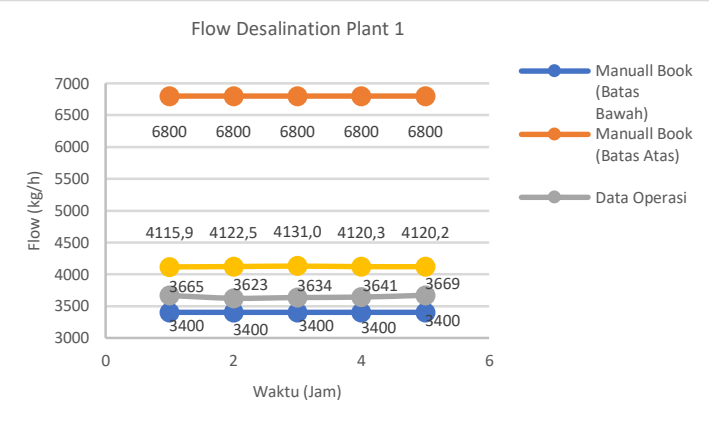

Gambar 5. Perbandingan flow desalination plant 1

Dari gambar 5, data operasi merupakan data flow desalination plant 1 ketika beroperasi sebelum adanya interkoneksi yakni ketika menggunakan suplai steam dari LP Aux blok 1 . Perhitungan merupakan flow input desalination plant 1 setelah adanya interkoneksi, yakni ketika menggunakan suplai steam dari CRH blok 3. Dari gambar 5, dapat dianalisa bahwa flow desalination plant 1 sebelum interkoneksi, yakni ketika menggunakan suplai steam dari LP Aux blok 1 (data operasi) dan sesudah penelitian yakni ketika menggunakan suplai steam dari CRH Blok 3 (perhitungan) masih sesuai dengan referensi manual book sehingga interkoneksi dari CRH Blok 3 ke Desalination plant 1 dapat dinyatakan layak digunakan.

\section{Pembahasan pressure dan flow desalination plant 2}

Dari data manual book, operasi desalination plant 2 dan perhitungan teoritis, maka dapat dibuat perbandingan pressure desalination plant 2 pada gambar 6 dan gambar 7 perbandingan flow desalination plant 2, sebagai berikut:

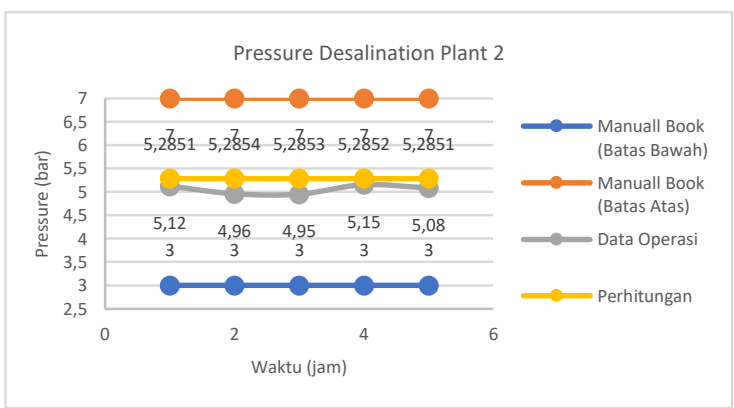

Grafik 6. Perbandingan pressure desalination plant 2 
Dari gambar 6, data operasi merupakan data pressure desalination plant 2, ketika beroperasi sebelum adanya interkoneksi, yakni ketika menggunakan suplai steam dari LP Aux blok 1. Perhitungan merupakan pressure input desalination plant 1 setelah adanya interkoneksi, yakni ketika menggunakan suplai steam dari CRH blok 3. Dari gambar 6, dapat dianalisa bahwa pressure desalination plant 2 sebelum interkoneksi, yakni ketika menggunakan suplai steam dari LP Aux blok 1 (data operasi) dan sesudah penelitian, yakni ketika menggunakan suplai steam dari CRH Blok 3 (perhitungan) masih sesuai dengan referensi manual book, sehingga interkoneksi dari $\mathrm{CRH}$ Blok 3 ke Desalination plant 2 dapat dinyatakan layak digunakan.

Dari gambar 7, data operasi merupakan data flow desalination plant 2 ketika beroperasi sebelum adanya interkoneksi, yakni ketika menggunakan suplai steam dari LP Aux blok 1 . Perhitungan merupakan flow input desalination plant 2 setelah adanya interkoneksi, yakni ketika menggunakan suplai steam dari CRH blok 3. Dari gambar 7, dapat dianalisa bahwa flow desalination plant 2 sebelum interkoneksi, yakni ketika menggunakan suplai steam dari LP Aux blok 1 (data operasi) dan sesudah penelitian, yakni ketika menggunakan suplai steam dari CRH Blok 3 (perhitungan) masih sesuai dengan referensi manual book, sehingga interkoneksi dari CRH Blok 3 ke desalination plant 2 dapat dinyatakan layak digunakan.

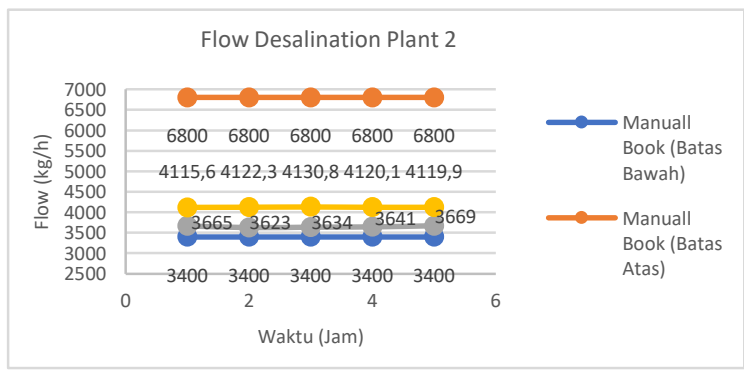

Gambar 7. Perbandingan flow desalination plant 2

\section{Pembahasan pressure dan flow desalination plant 3}

Dari data manual book, operasi desalination plant 3 dan perhitungan teoritis, maka dapat dibuat perbandingan pressure desalination plant 3 seperti pada gambar 8 dan perbandingan flow desalination plant 3 seperti pada gambar 9 , sebagai berikut:

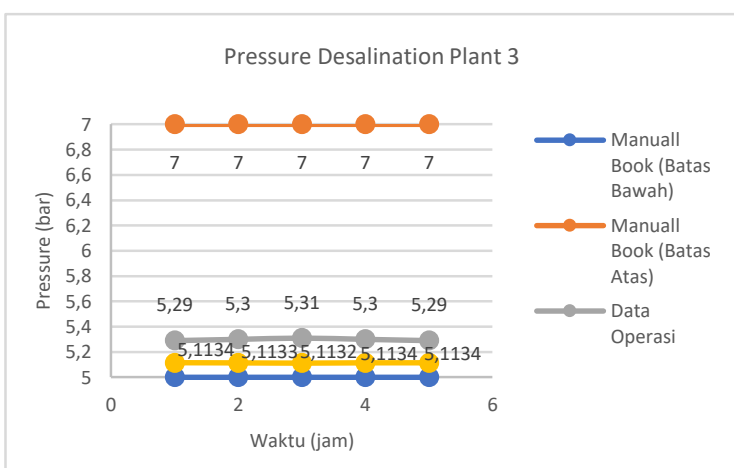

Gambar 8. Perbandingan pressure desalination plant 3

Dari gambar 8, data operasi merupakan data pressure desalination plant 3 ketika beroperasi sebelum adanya interkoneksi, yakni ketika menggunakan suplai steam dari CRH Blok 3. Perhitungan merupakan pressure input desalination plant 3 setelah adanya interkoneksi, yakni ketika menggunakan suplai steam dari LP Aux Blok 1. Dari gambar 8 dapat dianalisa bahwa pressure desalination plant 3 sebelum interkoneksi, yakni ketika menggunakan suplai steam dari CRH Blok 3 (data operasi) dan sesudah penelitian, yakni ketika menggunakan suplai steam dari LP Aux Blok 1 (perhitungan) masih sesuai dengan referensi manual book, sehingga interkoneksi dari LP Aux Blok 1 ke desalination plant 3 dapat dinyatakan layak.

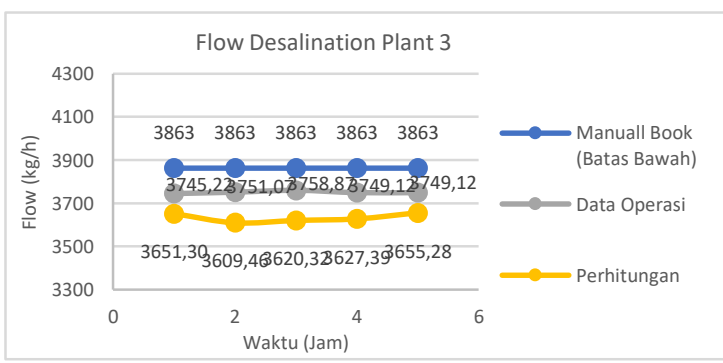

Gambar 9. Perbandingan flow desalination plant 3 
Sedangkan dari gambar 9, data operasi merupakan data pressure desalination plant 3 ketika beroperasi sebelum adanya interkoneksi, yakni ketika menggunakan suplai steam dari CRH Blok 3. Perhitungan merupakan pressure input desalination plant 3 setelah adanya interkoneksi, yakni ketika menggunakan suplai steam dari LP Aux Blok 1. Dari gambar 9 dapat dianalisa bahwa data flow operasi sebelum penelitian berada dibawah referensi manual book dengan deviasi $3 \%$, hal ini dipengaruhi oleh pembukaan control valve suplai uap ke desalination plant 3 . Deviasi sebesar $3 \%$ tidak mempengaruhi performance desalination plant karena masih bisa diatasi dengan pengaturan pembukaan control valve sesuai kebutuhan, sehingga desalination plant 3 tetap mampu beroperasi normal dalam load setter $60 \%$. Kemudian dari data perhitungan teoritis didapatkan nilai deviasi sebesar $5 \%$ dari referensi manual book. Sama seperti kondisi sebelum penelitian, deviasi sebesar $5 \%$ masih dapat dilakukan dengan pengaturan pembukaan control valve sesuai kebutuhan, sehingga desalination plant 3 tetap mampu beroperasi normal dalam load setter $60 \%$. Dari pembahasan diatas dapat dianalisa bahwa flow desalination plant 3 sebelum interkoneksi, yakni ketika menggunakan suplai steam dari CRH Blok 3 (data operasi) dan sesudah penelitian, yakni ketika menggunakan suplai steam dari LP Aux Blok 1 (perhitungan) masih sesuai dengan referensi manual book, sehingga interkoneksi dari LP Aux Blok 1 ke desalination plant 3 dapat dinyatakan layak

Dengan adanya interkoneksi line suplai desalination plant ini, maka desalination plant 1, 2 dan 3 dapat disuplai dari LP Aux Steam Blok 1 maupun CRH Blok 3. Sehingga ketersedian suplai uap untuk operasional desalination plant akan terjaga, walaupun kondisi operasi gas turbin yang start-stop dan adanya schedule pemeliharaan rutin maupun gangguan yang tidak diperkirakan. Sehingga desalination plant akan menjadi lebih handal untuk menunjang kegiatan operasional pembangkitan listrik di PLTGU Grati pasuruan.

\section{Pembahasan Ekonomi Biaya Operasi Desalination plant}

Biaya pengoperasian desal 1, 2 dan 3 beroperasi dengan menggunakan steam dari LP Aux Blok 1 paling murah karena ketika menggunakan steam dari LP Aux Blok 1, maka penurunan daya steam turbin blok 1 sebesar $26.400 \mathrm{kwh}$ dan penggunaan listrik hanya untuk peralatan-peralatan area desalination plant. Sedangkan ketika desal 1, 2 dan 3 beroperasi dengan menggunakan steam dari $\mathrm{CRH}$, penurunan daya steam turbin blok 3 sebesar $36.000 \mathrm{kwh}$, lebih banyak dibanding ketika menggunakan steam dari LP Aux Blok 1. Ketika desal 1, 2, dan 3 beroperasi dengan menggunakan steam dari Aux boiler, maka biaya pengoperasian desal paling mahal karena biaya penggunaan HSD (high speed diesel) yang mahal dan pemakaian listrik tidak hanya pada area desalination plant saja, namun juga pada area Aux boiler. Dari data diatas, maka dapat dibuat perbandingan biaya pengoperasian desal 1,2 , dan 3 seperti pada gambar 10 .

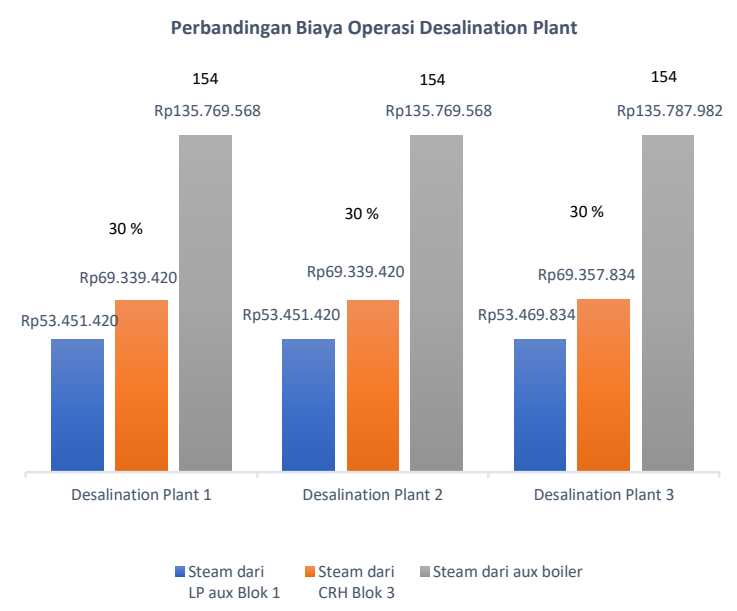

Gambar 10. Perbandingan biaya operasi desalination plant

Dari gambar 10, dapat dianalisa bahwa penggunaan steam untuk desalination plant yang paling murah yakni dari LP Aux steam Blok 1 dengan selisih 30\% dibanding CRH Blok 3 dan 
selisih 154\% dibanding Steam dari Aux boiler. Keuntungan yang diperoleh dari segi ekonomi dari interkoneksi, yakni dengan menghindari penggunaan $A u x$ boiler karena suplai steam bisa disuplai dari LP Aux steam blok 1 dan CRH Blok 3. Sehingga diperoleh keuntungan dari penurunan biaya operasi sebesar $154 \%$ atau sebesar 82.318.148 rupiah per hari.

\section{Kesimpulan}

Desain interkoneksi pada sistem suplai uap desalination plant dengan cara melepas dan memodifikasi posisi check valve pemisah antara desal 1, 2 dan 3 sehingga steam dari LP Aux blok 1 maupun CRH Blok 3 dapat mensuplai desal 1, 2, dan 3. Hasil analisa kelayakan desain interkoneksi suplai uap dari segi pressure dan flow desalination plant 1, 2 dan 3 sebelum penelitian (data operasi) dan sesudah penelitian (perhitungan) masih sesuai dengan referensi manual book sehingga dapat dinyatakan layak digunakan. Biaya operasional desalination plant 1, 2, dan 3 lebih murah ketika menggunakan suplai steam dari LP Auxiliarry Blok 1 dengan selisih $30 \%$ dibanding CRH Blok 3 dan selisih 154\% dibanding Steam dari Aux boiler. Keuntungan yang diperoleh dari penurunan biaya operasi sebesar $154 \%$ atau sebesar $82.318 .148,4$ rupiah per hari.

\section{Referensi}

[1] PT. Indonesia Power UPJP Perak Grati., 2016. Modul Pengoperasian Desalination plant . Pasuruan.

[2] Heavy Industries, M., 1995. Manual book Grati Combined Cycle Power Plant 1x500MW 3x100MW. Yokohama

[3] PT. PLN., 2017. Manual book Grati CCPP Extension Project 450 MW. Pasuruan.

[4] Salimi, M. and Amidpor, M., 2017. Modeling, simulation, parametric study and economic assessment of reciprocating internal combustion engine integrated with multi-effect desalination unit. Department of Mechanical Engineering, K.N. Toosi University of Technology, Energy Systems Division, Iran.

[5] Salimi, M., et al., 2018. Thermodynamic and economic optimization of multi-effect desalination unit integrated with utility steam network. Department of Mechanical Engineering, K.N. Toosi University of Technology.

[6] Elimelech, M. and Phillip, W., A., 2017. The Future of Seawater Desalination: Energy, Technology, and the Environment. American Association for the Advancement of Science.

[7] Qian, J., et al., 2017. Flow rate analysis of compressible superheated steam through pressure reducing valves. Water Research Center, Kuwait Institute for Scientific Research, Kuwait. Department of Energy Sciences, Lund University, Sweden.

[8] Munson, B. R., 2009. Fundamentals of Fluid Mechanics. United States of America: Don Fowley

[9] PT. PLN., 1996. Book Design, Operation \& Maintenace Manual Part 1 Design Manual B1. Sasakura Engineering,.co.ltd

[10] PT. PLN., 2017. Book GRMPO2118-M30-0034 Grati O \& M Manual (Combined Cycle). Pasuruan 